\title{
CHANCE FINDS OF ANTIQUITIES ON THE TERRITORY OF THE SAMARA GOVERNORATE IN THE SECOND HALF OF XIX - EARLY XX CENTURIES
}

\section{(C) 2018}

Pisareva Olesya Konstantinovna, master student of National History and Archaeology Department Samara State University of Social Sciences and Education (Samara, Russian Federation)

\begin{abstract}
In the paper, separate information about archaeological finds and predatory excavations on the territory of the Samara Governorate in the middle of the XIX-beginning of XX centuries is collected for the first time. The process of archaeological study of the Samara Governorate in the pre-revolutionary period of development of the Samara archaeology remains unexplored. As a result the author has made a set of archaeological discoveries and excavations made on the territory of the Samara Governorate in the second half of XIX-beginning XX centuries. The list of finds includes all facts of the discovery revealed during the research of archaeological sites and individual artifacts with indication of detection time, place, and composition of the find or treasure. The author revealed 142 evidences of found antiquities according to the research of the second half of XIX-early XX centuries. They are hoards of coins, jewelry, household items, religious objects and other finds accumulated in the scientific centers and museums in St. Petersburg, Moscow, Kazan, Samara, Saratov and Simbirsk. Many of finds are lost or their location is unknown. The issues raised in the paper are inseparably linked with the problem of accounting and protection of archaeological sites, preservation of cultural heritage.

Keywords: archaeology; protection of cultural heritage; Samara Governorate; Imperial Archaeological Commission; P.V. Alabin; archaeological site; list of finds; treasures; archaeological excavations; chance finds; XIX-XX centuries; objects of worship; grave mounds; stone statues; Public Museum; Samara Governor.
\end{abstract}

УДК 94 (367) : $929.5 \ll 13 / 14 »$

Статья поступила в редакцию 12.03.2018

\section{К ВОПРОСУ О РАЗВОДЕ И ВТОРОМ БРАКЕ КНЯЗЯ РОМАНА МСТИСЛАВИЧА}

(C) 2018

Абуков Сергей Навильевич, кандидат исторических наук,

доцент кафедры историографии, источниковедения, археологии и методики преподавания истории Донецкий нацииональный университет (г. Донецк, Донецкая Народная Республика)

Аннотация. Статья посвящена семейному конфликту рубежа XII-XIII вв. между киевским князем Рюриком Ростиславичем и галицким князем Романом Мстиславичем, женатым на его дочери Предславе. В историографии проблема представляется одной из наиболее дискуссионных, так как непосредственно связана с датировкой второго брака и происхождением второй жены Романа Мстиславича. Автор на основании имеющихся данных постарался определить хронологию событий, а также показать тесную связь семейных отношений князей Рюриковичей с политическими. Политический конфликт Романа с тестем Рюриком Ростиславичем, вместе с другими причинами, привел к прекращению семейных отношений с его дочерью. Ключевой темой в статье рассматривается вероятный механизм легитимации второго брака галицкого князя, позволившей ему развестись с первой женой и вступить во второй законный брак. По мнению автора, процесс развода с Предславой Романа Мстиславича не был единовременным актом. Несмотря на церковный развод, полученный от константинопольского патриарха, галицкий князь пошел на насильственное пострижение своей первой жены с целью окончательной легитимации своей новой семейной жизни и детей от второго брака.

Ключевые слова: Роман Мстиславич; Рюрик Ростиславич; Предслава Рюриковна; «княгиня Романова»; Всеволод Большое Гнездо; Ингеборга Датская; Русь; Киев; Константинополь; Галич; развод; конфликт; постриг; брак; жена; тесть; зять; князь; происхождение; патриарх; власть; отношения; Рюриковичи.

В начале XIII в. в междукняжеских отношениях произошло беспрецедентное событие: галицкий князь Роман Мстиславич заставил принять монашество киевского князя Рюрика Ростиславича, его жену Анну Юрьевну и дочь Предславу, свою бывшую жену. Этот акт стал наиболее известным, но всего лишь завершающим аккордом конфликта между Рюриком и экс-зятем, длившегося с перерывами со второй половины 90-х гг. XIII в., в котором, помимо пострижения, важными этапами были изгнание Романом жены, развод и его второй брак. Однако причины и обстоятельства этого экстраординарного события, как и вся эпопея с распадом первого брака Романа, не получили цельной и однозначной оценки.

Перипетии семейной жизни Романа с Предславой и пострижение Рюрика не прошли незамеченными в отечественной и в зарубежной историографии. Одни исследователи ограничились констатацией событий, другие постарались сделать его анализ и установить недостающие детали. Следует отметить, что ценные, по нашему мнению, сведения содержатся в труде B.Н. Татищева [1]. Говоря о проблематике вопроса в целом, следует назвать труды русских дореволюционных [2; 3], советских [4-7], украинских [8-10], российских [11-14], польских $[15 ; 16]$ и британских историков [17]. Анализ отдельных положений в их работах в контексте означенной темы будет сделан ниже.

Трудность для историка связана с состоянием древнерусских источников за период начала XIII в. С одной стороны, это прекращение Киевской летописи в составе Ипатьевского свода [18], поэтому основным источником остается просуздальская за этот период Лаврентьевская летопись [19] и близкие к ней северорусские летописи XV-XVI вв., содержащие важные дополнения, а также известия Новгородской первой летописи [20]. С другой стороны, затрудняет 
понимание событий неполнота и недосказанность наших источников. Настоящей проблемой является установление верной хронологии, поэтому особое значение приобретает работа Н.Г. Бережкова [21]. Ценные сведения содержатся также в русских [22], польских [23] и греческих источниках [24]. Очерчивая круг проблем статьи, по нашему мнению, можно выделить несколько ключевых вопросов: значение заключения для сторон первого брака Романа Мстиславича, причина и время расставания Романа Мстиславича с Предславой, легитимация развода и заключение второго брака Романа при живой первой жене, взаимоотношения Рюрика с экс-зятем до насильственного пострижения.

Время заключения брака Романа Мстиславича и Предславы Рюриковны, как и годы их рождения, не отражены источниками. Данная проблема является темой отдельного исследования, отметим только, что брак Предславы с Романом Мстиславичем следует отнести к 70-м гг. XII в. Видимо, Рюрик Ростиславич и Роман Мстиславич связывали большие политические надежды с этим союзом. Как отметил Л.В. Войтович, брак был попыткой получить поддержку смоленской ветви Мономашичей, чтобы подняться над уровнем удельного волынского князя [25, с. 472]. Н.Ф. Котляр, характеризуя статус Романа в период владимирского княжения, назвал его «дрібним удільним князем» («мелким удельным князем») [8, c. 38]. Это не совсем верно. Роман княжил во Владимире Волынском и был вторым по статусу после дяди луцкого князя Ярослава Изяславича с близкой перспективой возглавить линию Изяславичей. О важности этого брачного союза говорит близкое родство супругов, запрещенное церковью. Тогда это обстоятельство не смущала стороны. Роман не имел отца, и Рюрик фактически стал ему отцом. В 1188 г. мы видим Рюрика горячим сторонником своего зятя в его первой попытке овладеть Галичем. Внучка Рюрика Феодора Романовна, выданная ребенком за старшего из сыновей галицкого князя Владимира Ярославича, была элементом этой борьбы. Тогда же Ростиславичи для ослабления своих противников выпустили на политическую сцену находившегося под их покровительством члена галицкой династии сына Ивана Берладника Ростислава [18, стб. 663]. Когда же затея Романа не удалась и он лишится своего Владимира, то и здесь Рюрик вначале предоставляет ему владения на Киевщине, а затем добивается возвращения зятю владимирского стола [18, стб. 661-662].

В 1194 г. умер Святослав Всеволодович и Рюрик занял стольный Киев, хотя он не чувствовал себя прочно и нуждался в союзниках [18, стб. 681-683]. Судя по летописям, отношения Романа и Рюрика в 1195 г. почтительны и теплы. Роман называет тестя «отче» [18, стб. 684]. Рюрик, оказавшись под давлением Всеволода и интересами зятя, при поддержке митрополита Никифора пытался избежать конфликта, но это не удалось. Фактически отношения тестя и зятя были разрушены интригами суздальского князя, ввергшего юг Руси в конфликт, к которому подключились Ольговичи [18, стб. 683]. Всеволод Суздальский, поддерживая киевского свата, тем не менее действовал вполне самостоятельно, заключив сепаратный мир, что вызвало раздражение Рюрика, отобравшего у свата поросские города, но главной его проблемой стал восставший зять.
Под 1197 г., а никак не ранее, в летописи говорится уже о семейном конфликте Романа и его желании избавиться от своей жены, дочери Рюрика. Известие содержится в Лаврентьевской, но отсутствует в Ипатьевской летописи. Там же сказано, что Роман уже тогда хотел постричь отвергнутую супругу в монахини. Судя по летописному выражению «Романко поча пущати дчерь Рюрикову», события в семейной жизни развивались драматично и растянулись во времени [19, стб. 412-413]. Поэтому следует отнести окончательный разрыв супругов к 1198 г., а не к 1196 или 1195 г. [12, с. 104-105, прим. 220, 221; 26, с. 319]. Логика здесь проста и основывается на ходе летописных событий. После поражения в битве при Мозгаве в Польше в сентябре 1195 г. Роман вынужден был покориться Рюрику [18, стб. 687]. Возобновление отношений с тестем не могло быть вне примирения с женой, если семейные неурядицы уже имели место. Одно без другого немыслимо. Едва ли не главным аргументом в пользу ранней датировки развода остается Вицентий Кадлубек [23]. Полагаться на польский источник трудно, так как его изложение русских событий тенденциозно, неточно и вызывает немало вопросов. Особенно важен факт негативного отношения польского хрониста к Роману Мстиславичу [12, с. 157]. Хронист прямо обвиняет галицкого князя в зверствах и зависимости от польских князей, якобы правившего с их высокой руки [23].

Кроме того, необходимо развести два понятия: прекращение отношений между супругами и их разъезд и официальный развод, оформленный церковью. Едва ли глагол «пущати» можно представить как узаконенное расторжение брака, если о нем, как отмечалось выше, пишет Кадлубек. На эту проблему обращали внимание исследователи [13, с. 141 , прим. 12]. К тому же, признав раннюю дату прекращения отношений супругов, мы получаем большой хронологический разрыв между обоими браками Романа и его родившимися сыновьями, что трудно объяснить, если учесть два обстоятельства: желание князя поскорее обзавестись наследником и традицию князей торопиться с новым браком. Только с возобновлением конфликта с тестем начались и семейные проблемы Предславы с мужем. Н.Ф. Котляр считал датой развода 1197 г. [27, с. 196]. Заметим, что к 1198 г. относит конец брака В.Н. Татищев [1, с. 164]. Лаврентьевская летопись уже больше не называет Романа зятем Рюрика [19, стб. 413-418]. Действительно, при уточнении хронологии летописи мы видим Предславу в Киеве зимой 1198/9 г. при рождении ее племянницы и затем в сентябре 1199 г. на торжествах в Выдубичах [18, стб. 708, 711; 21, с. 210-211]. В.Н. Татищев связывает поведение Романа с женой его местью тестю, которому он не мог тогда ничем ответить [1, с. 164]. Как повод для разрыва брака Роман именно тогда мог использовать близкое родство с супругой, а именно недозволенную по церковным канонам шестую степень [28]. Можно убедиться, что острый конфликт между тестем и зятем на Руси приводил к полному или временному распаду брака, как это было в начале ХІІ в. между Владимиром Мономахом и Ярославом Святополчичем или в начале XIII в. между Мстиславом Удатным и Ярославом Всеволодовичем [18, стб. 501-502; 29, с. 28].

Трудно согласиться с мнением, что Роман искал более выгодный брак $[17$, с. 61$]$. Дочь киевского князя - лучшая партия для Рюриковича. Как видим, при- 
чины были совсем другими. Помимо политических причин, важно то, что у Романа к возрасту почти 40 лет от Предславы не было сыновей. Возможно, он потерял на это надежду. Поэтому политический конфликт представляется тесно связанным с семейным. Для князя именно сын являлся полноценным наследником и преемником отца. Незамужних дочерей же Рюриковичи «забывали» даже упомянуть в завещаниях [30, с. 16]. Поведение Романа с дочерью вызвало гнев Рюрика. Это было оскорбление, как и оценивает это поздняя Никоновская летопись [31, c. 29]. Любопытно, что Киевская летопись умалчивает об этом неприятном для киевского князя моменте. Настроить против Романа он постарался Всеволода Суздальского, хотя для этого была названа политическая причина, а не семейная [19, с. 412-413]. В обращении Рюрика к Всеволоду Роман Мстиславич становится «Романко» (к сожалению, неясен смысл этой формы имени, но угадывается уничижительный подтекст).

К 1199 г. Роман Мстиславич значительно усилился, захватив Галич. Что касается его семейной жизни, то из последующих сообщений становится понятным, что: 1) он порвал с Предславой; 2) развод получил правовой статус; 3) галицкий князь вступил во второй брак; 4) его сыновья в этом браке Даниил и Василько были законными и никто не подвергал сомнению их законнорожденность. Более того, появление нехарактерных для Мстиславичей имен говорит о присутствии некоей другой сильной антропонимической традиции. Но каким образом мог быть расторгнут первый брак при живой жене и признан второй? Как это могло произойти и кто узаконил развод? Едва ли это был киевский митрополит Никифор, поддерживающий Рюрика.

Ключевым для понимания поставленной проблемы является знаменитое в историографии представительное посольство Романа Мстиславича в Константинополь (там оно зафиксировано очевидцем 21 мая 1200 г.) во главе Твердятой Остромиричем [22, стб. 78-79]. Одним из его целей могло быть именно получение разрешения на развод от константинопольского патриарха. Как верно заметил А.В. Горовенко, «именно он и являлся тем единственным человеком, который мог решить проблему Романа» [12, c. 84]. То, что русские князья в щекотливых вопросах заключения брака обращались за помощью напрямую к патриарху, известно из летописей [32, стб. 57]. Получить его было тем легче, чем более нестабильным становилось положение Византии при Алексее III Ангеле, так и при условии заинтересованности греков в союзе с Романом перед лицом многочисленных внешних врагов. Судя по сообщениям Никиты Хониата, такой союз был заключен против половцев [24]. В любом случае, если бы Роману нужно было решение о разводе, то он бы его получил. Нельзя исключить, что одновременно с разводом речь зашла о заключении выгодного для Царьграда второго брака Романа с представительницей византийской правящей элиты. Важно и еще одно обстоятельство: о посольстве Романа 1200 г. нам известно, можно сказать, случайно, поэтому оно могло быть не единственным.

Что касается вопроса о происхождении «княгини Романовой», то он представляется одним из наиболее сложных в генеалогии Рюриковичей и породил 164 огромную литературу [10, с. 480-487]. Не пытаясь вмешаться в этот спор, который лишь косвенно касается заявленной темы, отметим, что едва ли второй женой Романа могла быть наложница [33, с. 99]. Достаточно популярной у исследователей является версия о боярском происхождении второй жены Романа, выдвинутая почти 70 лет назад [4, с. 194]. «Второе дыхание» эта гипотеза, имеющая свои сильные и слабые стороны, получила благодаря украинскому историку Н.Ф. Котляру [34, с. 161-162]. Однако, вопервых, летописи отмечают высокий статус вдовы Романа на Руси, в Польше и Венгрии. Во-вторых, полное признание ее легитимности и факта родства с западными правителями. В-третьих, загадочные греческие имена в династии Романовичей. В-четвертых, печальный опыт боярских браков и конкубината последних представителей первой галицкой династии должен был стать серьезным предостережением для Романа, нуждавшегося в законном и высокородном наследнике. Отсутствие законных детей Владимира Ярославича погубило династию Ростиславичей. Более того, мы не знаем примеров браков князей с боярскими дочерями в домонгольской Руси, за исключением Новгорода, который находился на особом положении и только подтверждает общее правило. Тем не менее нет следов прямого родства княгини с Рюриковичами, Арпадами, Пястами. Поэтому «греческая» гипотеза, условно распадающаяся на «императорскую» и «сановную», остается довольно популярной. Напомним вкратце аргументы польского историка И. Грали, который предположил, что вторая жена Романа была выходцем из знатного и древнего рода Каматерос [15, s. 116-123]. Впрочем, нельзя исключить, что избранницей галицкого князя стала и женщина императорской семьи Ангелов. Однако это только гипотеза, которой нет прямых подтверждений. Никита Хониат, весьма высоко отозвавшийся о Романе, охотно упоминающий матримониальные связи императорского дома, ничего не сообщает о сватовстве и жене галицкого князя [24]. Вообще, к сожалению, мы не знаем важных для нас фактов: как проходила легитимация не рожденных в браке княжеских детей; как члены династии и общество смотрели на бастардов; насколько они были полноправны в наследования столов и существовали ли в этом региональные отличия, так как точно известные примеры наличия внебрачного потомства связаны с югозападной Русью. Их выяснение позволяет ответить и на конкретный вопрос статуса второго брака Романа Мстиславича. Похоже, что на Руси правовой и социальный статус внебрачных сыновей был выше, чем в Западной Европе.

Как следует думать, летом 1200 г. послы Романа привезли ему патриаршую грамоту о разводе и, возможно, супругу. Логично, что около 1201 г. у Романа родился первенец с необычным для Рюриковичей именем Даниил [18, стб. 717]. Рюрику тяжело было признать волю императора и патриарха, как и факт явного предпочтения византийской элитой ему Романа. Семейная жизнь его дочери с галицким князем закончилась и де-юре, но могла ли семья Рюрика забыть бесчестье? Едва ли. Какие же формальные поводы должны были узаконить развод? Думается, проблем с этим не было. Во-первых, это близкая степень родства супругов и нарушение византийского 
церковного законодательства в этом вопросе, на что обратил внимание А.В. Горовенко [12, с. 84]. Вовторых, возможно, отсутствие сыновей или неспособность супруги подарить сына. Впрочем, и первого было достаточно. Любопытно, что в Европе XIIXIII вв. подобные поводы для разводов и вмешательство римских пап в семейную жизнь монархов являлись обычной практикой. Заслуживает внимания еще одна семейная драма этих лет - Ингеборги Датской с французским королем Филиппом II, который после заключения брака с ней в 1193 г. отверг супругу и женился в третий раз на Агнессе Меранской в 1196 г., всячески притесняя Ингеборгу, несмотря на увещевания папы возобновить с ней брак [35, р. 40 49]. История на другом конце Европы, может быть, и не имела такого значения, если бы не вызвала такой резонанс, а сама датская принцесса не приходилась Роману троюродной сестрой по линии отца и двоюродной племянницей по линии матери, хотя и не через Владимира Всеволодовича, как ошибочно считалось [7, с. 525, 527]. Вероятно, новости об этом через Польшу попали на Русь. Грамота константинопольского патриарха официально снимала вопросы о личной жизни галицкого князя и заставляла признать развод. Греки хорошо знали о конфликте Рюрика и Романа и встали на сторону последнего [24].

Как ответ на действия Романа можно рассматривать задуманный Рюриком поход на Галич с участием родичей и Ольговичей, приведший Рюрика к полному фиаско и захвату Киева войсками Романа, пользовавшегося симпатиями горожан и тюркского населения Киевщины. В январе 1203 г., обозленный на киевлян Рюрик с Ольговичами и половцами устроил погром Киева, сопровождавшийся жестокими грабежами, убийствами и пленением горожан [18, стб. 418-419]. Хотя некоторые историки считают описание погрома столицы Руси клишированным, сам факт масштабного опустошения города не подлежит сомнению $[17$, с. 63-64]. Любопытные подробности новгородской летописи красочно дополняют общую картину [20, с. 240]. Историки видят в этом месть Рюрика нелояльным киевлянам [8, с. 45]. Сам Рюрик после погрома остался в Овруче. Б.А. Рыбаков связывает выбор этого города отсутствием надежд закрепиться в разоренном Киеве [6, c. 495]. Последовавшее затем примирение Рюрика с Романом и возвращение Ростиславича на киевский стол следует рассматривать и как факт временного признания его развода с Предславой. Однако все же вопросы оставались. Если Лаврентьевская летопись перестает называть Романа зятем, то поздние летописи упорно так именуют Романа Рюрика до самого 1204 г. и тем самым игнорируют новую реальность в жизни галицкого князя [31, с. $36 ; 32$, Тверской сборник. стб. 294].

Заключительным актом драмы во взаимоотношениях бывшего тестя и зятя стала катастрофа 1204 г. На переговорах в Треполе Роман схватил Рюрика и отправил его на пострижение в Киев. Вместе с ним были пострижены жена князя Анна и бывшая супруга Предслава [19, стб. 420-421]. Этим шагом Роман решительно хотел вычеркнуть бывшего тестя из политической жизни Руси и поставить точку в затянувшемся конфликте. Как видно, помимо политических причин продолжал тлеть и давний семейный конфликт. Одновременно Роман убрал из светского мира бывшую жену, которая мозолила ему глаза после второго брака. Теперь уже никакие доводы не могли поставить под сомнение второй брак Романа. Давние обиды вновь выплеснулись наружу - насильственно была пострижена и теща, никак не связанная ни с распределением волостей, ни с матримониальными отношениями Романа. В княжеских отношениях политическое и личное представляло эклектическую смесь. При жизни Романа Рюрик явно боялся покинуть стены монастыря. Гибель галицкого князя 19 июня 1205 г. в засаде под польским Завихвостом, представленная его противниками как невероятная и крупнейшая победа [14, с. 347], дала возможность Рюрику выйти из монастыря, но его жена не только осталась в монастырских стенах, но и приняла схиму [19, стб. 426]. О постриженной Предславе летописи умолчали, так как в ее положении, как видно, не произошло изменений.

Подводя итог, следует отметить, что, породнившись, Роман и Рюрик связывали с этим союзом большие политические планы. Первоначально отношения между тестем и зятем были как нельзя лучше. Рюрик оказывает помощь Роману в его военнополитических делах. Но с 1195 г. начинается острый политический конфликт с тестем, к которому позднее добавилось желание Романа избавиться от нелюбимой жены Предславы, не подарившей его сына. Как видно, это был не единовременный процесс, но в 1197-1198 гг. произошел окончательный разрыв брака. Действия Романа были оскорбительны для Рюрика и усиливали взаимный антагонизм. Как видно, в 1200 г. через свое посольство в Константинополе Роман получает от патриарха развод под предлогом близкого родства супругов, после чего вступает во второй брак. Политические выгоды византийцев облегчили сам развод и позволили галицкому князю начать новую семейную жизнь, однако не все на Руси признали такой исход дела. Перманентный конфликт между бывшими тестем и зятем продолжался и закончился в 1204 г. пострижением Рюрика, его жены и экс-супруги Предславы, как еще ранее планировал галицкий князь, тем самым сняв вопрос легитимности второго брака с повестки дня.

\section{Список литературы:}

1. Татищев В.Н. История Российская. Т. 3. М.-Л.: Наука, 1964. 338 с.

2. Карамзин Н.М. История государства Российского. Т. II-III. М.: Наука, 1991. 832 с.

3. Соловьев С.М. История России с древнейших времен. Кн. 1. М.: Мысль, 1988. 797 с.

4. Пашуто В.Т. Очерки по истории ГалицкоВолынской Руси. М.: Издательство АН СССР. 333 с.

5. Толочко П.П. Древняя Русь. Киев: Наукова думка, 1987. 246 с.

6. Рыбаков Б.А. Киевская Русь и русские княжества в XII-XIII вв. М. Наука, 1982. 566 с.

7. Родоводи // Літопис Руський / Переклад і коментар Л. Махновця. Київ: Дніпро. 1989. 591 с

8. Котляр М.Ф. Данило Галицький. Біографічний нарис. Київ: ВД Альтернативи, 2002. 328 с.

9. Головко О. Князь Роман Мстиславич та його доба. Нариси історії політичного життя Південної Русі XII - початку XIII століття. К.: Стилос, 2001. $248 \mathrm{c}$ 
10. Войтович Л.В. Галицько-волинські етюди. Біла Церква: Вид. Пшонківський О.В., 2011. 480 с.

11. Майоров А.В. Из истории внешней политики Галицко-Волынской Руси времен Романа Мстиславича // Древняя Русь. Вопросы медиевистики. 2008. № 4 (34). С. 78-96.

12. Горовенко А.В. Меч Романа Галицкого: князь Роман Мстиславич в истории, эпосе и легендах. Тамбов: Изд-во ТГУ им. Г.Р. Державина, 2010. 307 с.

13. Литвина А.Ф., Успенский Ф.Б. Насильственный постриг княжеской семьи в Киеве: от интерпретации обстоятельств к реконструкции причин // Средневековая Русь. Вып. 10: к 1150-летию зарождения российской государственности / отв. ред. А.А. Горский. М., 2012. С. 135-169.

14. Щавелева Н.И. Древняя Русь в «Польской истории» Яна Длугоша (книги I-VI): Текст, перевод, комментарии / под ред. и с доп. А.В. Назаренко. М.: Памятники исторической мысли, 2004. 495 с.

15. Grala H. Drugie małźeństwo Romana Mścisławowicza // Slavia Orientalis. Rocz. XXXI. Warszawa, 1982. № 3-4. P. 115-127.

16. Домбровский Д. Генеалогия Мстиславичей. Первые поколения (до начала XIV в.) / Пер. с польского и вступ. слово к рус. изд. К.Ю. Ерусалимского и О.А. Остапчук. СПб.: Дмитрий Буланин, 2015. $880 \mathrm{c}$.

17. Феннел Дж. Кризис средневековой Руси 1200 1304 гг. М.: Прогресс, 1989. 296 с.

18. ПСРЛ. Ипатьевская летопись. Т. 2. М.: Языки славянской культуры, 2001. 648 с.

19. ПСРЛ. Лаврентьевская летопись. Т. 1. М.: Языки славянской культуры. 2001. 496 с.

20. ПСРЛ. Новгородская первая летопись старшего и младшего изводов. М.: Языки русской культуры. $2000.720 \mathrm{c}$.

21. Бережков Н.Г. Хронология русского летописания. М.: Издательство Академии наук СССР. 377 с.

22. Путешествіе Новгородскаго архіепископа Антонія въ Царьградъ в конце 12-го столетія / С предисл. и примеч. П.И. Савваитова. СПб.: Тип. Имп. Академіи Наукъ, 1872. 188 стб.

23. Щавелева Н.И. Хроника магистра Винцентия Кадлубка // Польские латиноязычные средневековые источники. М.: Наука, 1990. С. 76-140.

\section{DIVORCE AND SECOND MARRIAGE OF KNYAZ ROMAN MSTISLAVICH}

(C) 2018

Abukov Sergey Navilievich, candidate of historical sciences,

associate professor of Historiography, Source Studies, Archeology and Methods of History Teaching Department Donetsk National University (Donetsk, Donetsk People's Republic)

Abstract. The paper focuses on a family conflict at the turn of XII-XIII centuries between the Kievan Knyaz Rurik Rostislavich and the Galician Knyaz Roman Mstislavich, who married Rurik's daughter Predslava. In historiography the problem is one of the most controversial, since it is directly related to the dating of the second marriage and the origin of the second wife of Roman Mstislavich. The author, on the basis of available data, tried to determine the chronology of events, as well as to show close family relations between the knyazes of Rurik dynasty and the policy. The political conflict between Roman and his father-in-law Rurik Rostislavich, together with other reasons, led to the termination of his family relations with his daughter. The key topic in the paper is the probable mechanism of Galician knyaz' second marriage legitimation, which allowed him to divorce his first wife and get married for the second time. According to the author, divorce from Predslava was not a one-time act for Roman Mstislavich. Despite the church divorce received from the Patriarch of Constantinople, the Galician knyaz went to the violent tonsure of his first wife to finally legitimize his new family life and children from his second marriage.

Keywords: Roman Mstislavich; Rurik Rostislavich; Predslava Rurikovna; «Romanov's wife»; Vsevolod Large Nest; Ingeborga of Denmark; Rus'; Kiev; Constantinople; Galich; divorce; conflict; tonsure; marriage; wife; fatherin-law; brother-in-law; knyaz; origin; patriarch; power; relations; Rurikids. 